\title{
Hairy Root Cultures-A Versatile Tool With Multiple Applications
}

\author{
Noemi Gutierrez-Valdes ${ }^{1}$, Suvi T. Häkkinen ${ }^{1}$, Camille Lemasson ${ }^{2}$, Marina Guillet ${ }^{2}$, \\ Kirsi-Marja Oksman-Caldentey ${ }^{1}$, Anneli Ritala ${ }^{1 \dagger}$ and Florian Cardon ${ }^{2 * \dagger}$ \\ ${ }^{1}$ VTT Technical Research Centre of Finland Ltd., Espoo, Finland, ${ }^{2}$ Samabriva SA, Amiens, France
}

OPEN ACCESS

Edited by:

Inge Broer,

University of Rostock, Germany

Reviewed by:

Sumita Jha,

University of Calcutta,

India

Javier Palazon,

University of Barcelona, Spain

Alejandra Beatriz Cardillo,

University of Buenos Aires, Argentina

Rosa M. Cusido,

University of Barcelona, Spain

*Correspondence:

Florian Cardon

florian.cardon@samabriva.com

${ }^{\dagger}$ These authors share last authorship

Specialty section:

This article was submitted to

Plant Biotechnology,

a section of the journal

Frontiers in Plant Science

Received: 11 October 2019 Accepted: 13 January 2020

Published: 03 March 2020

Citation:

Gutierrez-Valdes N, Häkkinen ST,

Lemasson C, Guillet $M$,

Oksman-Caldentey K-M, Ritala A

and Cardon F (2020) Hairy Root

Cultures - A Versatile Tool With

Multiple Applications.

Front. Plant Sci. 11:33.

doi: 10.3389/fp/s.2020.00033
Hairy roots derived from the infection of a plant by Rhizobium rhizogenes (previously referred to as Agrobacterium rhizogenes) bacteria, can be obtained from a wide variety of plants and allow the production of highly diverse molecules. Hairy roots are able to produce and secrete complex active glycoproteins from a large spectrum of organisms. They are also adequate to express plant natural biosynthesis pathways required to produce specialized metabolites and can benefit from the new genetic tools available to facilitate an optimized production of tailor-made molecules. This adaptability has positioned hairy root platforms as major biotechnological tools. Researchers and industries have contributed to their advancement, which represents new alternatives from classical systems to produce complex molecules. Now these expression systems are ready to be used by different industries like pharmaceutical, cosmetics, and food sectors due to the development of fully controlled large-scale bioreactors. This review aims to describe the evolution of hairy root generation and culture methods and to highlight the possibilities offered by hairy roots in terms of feasibility and perspectives.

Keywords: Rhizobium rhizogenes, Agrobacterium rhizogenes, hairy roots, recombinant proteins, specialized metabolites, molecular farming

\section{INTRODUCTION}

Between the 1930s and the 1960s, hairy roots (HRs) were studied primarily as a sign of pathogen invasion in horticultural plants (Doran, 2013). Only until the 1970s to the 1980s, Agrobacterium rhizogenes was identified as the bacterial agent that, through the gene transfer of the bacterial Ri (root-inducing) plasmid, induces HR syndrome (Chilton et al., 1982; Gelvin, 2009). This important revelation prompted several studies that have helped to develop the hairy root cultures (HRCs) technology. We now know that HRs arise from the wounding site of plantlets when they are infected by $A$. rhizogenes, a symbiotic bacterium currently taxonomically renamed Rhizobium rhizogenes. The infection takes place upon of specific bacterial DNA fragments (T-DNA) from its root-inducing plasmid (pRi) into plant cells (Chilton et al., 1982). Even when the plant responds to bacterial infection by triggering the expression of several defense-related proteins to suppress the pathogen, $R$. rhizogenes has evolved mechanisms to take advantage of those plant defense proteins by counteracting an action that consequently dismounts the plant defense pathways (Sevón and Oksman-Caldentey, 2002; Mauro et al., 2017). To date, every system for recombinant protein production presents its limitations. For instance, inability to produce and/or secrete functional complex proteins (e.g. bacterial systems), risk of viral transmission and toxic molecules (e.g. 
bacterial systems, mammalian cells), or very high production costs (e.g. mammalian cells) (Cardon et al., 2019). Since the early 2000s, the production of therapeutic proteins using transgenic plants appeared to offer a number of major advantages over other expression systems including safety (no risk of humanthreatening viral contamination), low upstream costs, and complex glycosylation. Plant cell suspensions and HRCs combine the intrinsic advantages of plants and a confinement of production. In comparison to cell suspensions, HRCs present several advantages such as genotypic and phenotypic stability and possible extracellular secretion of expressed proteins (also referred to as rhizosecretion) offering a convenient method for target proteins purification in a well-defined protein-deficient medium (Wang and $\mathrm{Wu}, 2013$ ). HRCs are capable for the production of complex compounds and high scalability (Häkkinen and Ritala, 2010; Stoger et al., 2014). In this context, the production of recombinant proteins has been considered a promising application of HRCs. It allows the expression of recombinant proteins by roots grown in bioreactor and their secretion in the culture medium under controlled and confined conditions.

Likewise, $R$. rhizogenes-mediated transformation has allowed a successful production of different chemical compounds also known as specialized metabolites or secondary metabolites which correspond to complex molecules naturally present in the plants and displaying interesting features at a pharmacological, cosmetic and nutraceutical level. According to literature analysis, over the past three decades, $R$. rhizogenes transformation has also been used to elucidate physiological processes and biosynthetic pathways, to generate plant-derived molecules, to assist molecular breeding, to improve phytoremediation strategies, and to produce therapeutic recombinant proteins (Georgiev et al., 2012; Häkkinen and Oksman-Caldentey, 2018).

Due to their technological and economic advantages, the development of HRCs has gained an increasing interest by academic research teams, biotechnology companies and pharmaceutical industries. To exemplify, according to SCOPUS databases, from 01/2012 to 11/2018, 607 articles dealt with research using HRCs. According to PubMed databases, from $01 / 2012$ to $02 / 2019,767$ scientific publications were identified with the keywords "hairy roots" or "hairy root" or "transformed root cultures" or "transformed root culture." When the terms HRCs and recombinant protein (RP) are inquired, different subject areas are identified, from which the three most relevant are Biochemistry, Genetics and Molecular Biology (38.2\%), Immunology and Microbiology (17\%), and Agricultural and Biological Sciences (17\%). In SCOPUS database, 78 patents dealing with recombinant protein production using HRCs were identified. Most of these patents were published in 2017 and mainly comprise the description of methods to increase the production yield in plant material (Medina-Bolivar and Yang, 2017). Some are specifically dedicated to increase the secretion of recombinant proteins (Jost et al., 2014). Globally, as illustrated in Figure 1, the scientific research related to the HRCs is on the rise since the 1990s, with a marked increasing interest during the last 15 years (from PubMed databases).

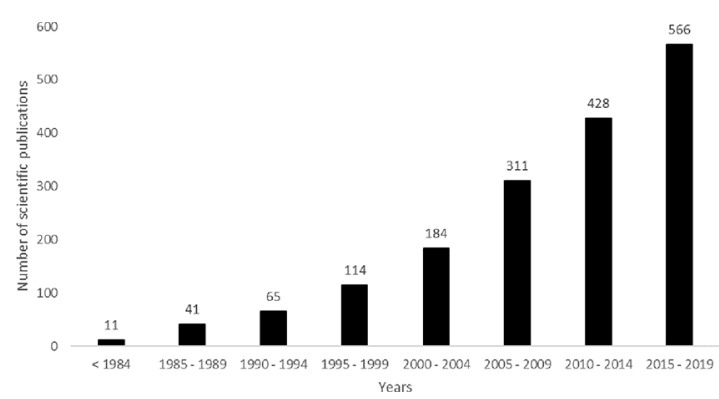

FIGURE 1 | Overtime evolution of the number of scientific publications dealing with hairy roots (HRs) (date of access, December 16th, 2019 with key words "hairy roots" or "hairy root").

\section{R. RHIZOGENES: A PARTICULAR BACTERIUM}

R. rhizogenes is a gram-negative soil bacterium inhabiting near plant roots and ultimately causing in the infected plant host the so-called "hairy root syndrome." This syndrome consists of a non-geotropic branching root overgrowth at the site of infection (Guillon et al., 2006). The molecular events involved in the formation of the so-called HRs are not yet entirely understood. However, the genetic transformation process can be divided into the following stages: (a) Rhizobium-perceiving phenolic compounds e.g. acetosyringone are released by the explant usually after wounding, activating attachment of the bacteria to explant/root cells; (b) processing of the T-DNA into bacterial cells and $\mathrm{T}$ complex formation ( $\mathrm{T}$ strands and other associated proteins); (c) transfer of $\mathrm{T}$ complexes from the bacteria to the plant host genome; (d) T-DNA incorporation and expression in the plant genome; and (e) HRs emerging from the infection site (Georgiev et al., 2012).

The T-DNA of the Ri plasmid is randomly integrated into the plant genome and expressed as mRNA. Various loci such as the so-called vir region of the pRi, T-DNA, and chromosomal virulent $(c h v)$ genes are vital for efficient transformation. These genes consist of virD1 and virD2, that portray proteins that attach to and cut DNA at 25-bp T-DNA border repeat sequences (Georgiev et al., 2012). Proteins translated from virE1 and virE2 genes are also significant as they shield $\mathrm{T}$ strands from nuclease digestion and ease their integration into the plant chromosome. Even though some $R$. rhizogenes strains do not possess these genes, they still transfer $\mathrm{T}$ strands effectively because of the existence of the pRi GALLS gene portraying a protein with a nuclear localization signal and helicase activity (Gelvin, 2009). The T-DNA contains two independent sequences, namely left and right borders, TL and TR, respectively. TL-DNA and TRDNA are usually independently transferred and stably integrated into the genome of the host plant (Chandra, 2012). However, only the TL-DNA is vital and sufficient for HR induction. After sequencing of the TL-DNA, four open reading frames were discovered as essential for $\mathrm{HR}$ induction (rolA, rolB, rolC, and rolD). The products of these rol genes have specific functions in 
the formation; however, the rolB gene seems to be the most relevant in the induction. Also the rol-genes have a big influence on the phenotype of the plants regenerated from the HRCs (Sevón et al., 1997). In a loss-of-function study, it was discovered that the knock-out of the rolB gene causes the plasmid to be avirulent (Mauro et al., 2017). Additionally, the rolB gene showed to be involved in RNA silencing pathways through microRNA overexpression (Bulgakov et al., 2015). Finally, the rolB gene of $R$. rhizogenes is involved in the activation of the transcription factors of most specialized metabolites in HRCs as well as on the expression of chaperone-type proteins (Bulgakov et al., 2016; Bulgakov et al., 2018). However, the function of this activator is still poorly understood. Very recently, a critical role of rolA in the long-term cultivation was also discovered, opening up a new research area to fully understand the rol genes function (Veremeichik et al., 2019). Overall, rol genes are described as modulators of plant growth and cell differentiation and could also mediate uncommon signal transduction pathways in plants (Bulgakov, 2008). Further research is still required to have a better understanding of all molecular events concerning HR induction.

\section{HR PROCESS: GENERATION, CONSERVATION, AND CULTURE}

The first comprehensive publication on the state of the art technology on HRCs (Hairy Roots: Culture and Applications) (Doran, 1997) provided information on laboratory protocols for initiation, culture, and genetic transformation of HRs. Additionally, the book described applications in plant propagation, alkaloid synthesis, and downstream processing considerations for largescale HRCs. Nowadays, the laboratory protocols for HRC are highly comparable to those previously used.

To develop an optimal HRC system, the complexity of the molecules to be produced has to be considered very early in the process (such as molecular weight, potential toxicity, etc...), along with the intrinsic properties of the plant species selected for HR induction (such as growth capacity, ability to be transformed, etc...). Actually, some species are more efficient than others in terms of productivity. This is particularly true regarding the production of specialized metabolites for which the choice of the plant to infect will influence on the metabolites to be produced. For example some hemp species have to be privileged according to the cannabinoid compounds to be produced (De Meijer et al., 2003). The choice of plant species also needs to be considered for the production of recombinant proteins. As an example, one of the plant species among the most commonly used to produce recombinant proteins is Nicotiana tabacum. It has been demonstrated that this species is less efficient than Brassica rapa rapa for the production and secretion at least of eGFP under the same HRC conditions (Huet et al., 2014). Moreover, the stability over time on the production capacity of the HRs has to be considered (Huet et al., 2014; Häkkinen et al., 2016). Finally, when possible, the safety of the plant species has to be taken into account in particular for pharmaceutical application (e.g. edible plants). Globally, the two most important criteria, when selecting the most appropriate plant species for HRC, are its ability to produce and secrete high amounts of the molecule of interest and its biomass production capacity.

Usually, HRC induction involves cultivation of sterile wounded plant explants that are directly inoculated with a $R$. rhizogenes (Figure 2A). When the goal is to produce recombinant proteins, this bacteria have to be first genetically engineered, so as to portray the genes of interest to be later expressed by the HRs. Certain plant species, such as monocotyledonous species, are considered recalcitrant as they cannot be transformed using this method. For these recalcitrant species, a technique called sonication-assisted $R$. rhizogenesmediated transformation (SAArT) has been demonstrated to be suitable for inducing HRCs (Georgiev et al., 2015). The explants are then treated with antibiotics to eradicate the bacteria. The resultant neoplastic HRs with multiple branches grow on hormone-free media. At this point, to confirm that these roots are indeed HRs and not adventitious roots, and that the $R$. rhizogenes was efficiently eradicated, PCR is normally performed using primers that amplify rol and vir genes. If a heterologous gene has been integrated in $R$. rhizogenes bacteria, parallel PCR using transgene-specific primers is also used in order to confirm its integration in the HR genome.

Once developed and selected, the HR strains can undergo different maintenance procedures according to financial and practical constraints (Figure 2B). Currently, the mainly used preservation method is a monthly subculture of individualized HRs on solid and/or liquid media. This method is timeconsuming, expensive, and may present high risks of contamination and eventual loss of original strains. Another HR preservation alternative that avoids the abovementioned problems is cryopreservation of the HR clones (Georgiev et al., 2012). The cryoconservation refers to the storage of a biological material (as plant) for a long-term period in specific conditions to avoid any genetic modification or alteration that may threat the ability of the material to produce a well-characterized molecule of interest. To date, three different approaches have been proposed for the cryopreservation of plant material cultures in liquid nitrogen: (a) the slow cooling technique, (b) the vitrification method, and (c) the dehydration of immobilized cells within alginate. Few articles describe methods for cryoconservation of plant materials and especially HRs (Hirata et al., 1998; Xue et al., 2008; Lambert et al., 2009; Häkkinen et al., 2016). These methods present advantages to be transferable in biobanks and to be in agreement with the usual definition of a Master and Working transgenic bank, thus facilitating the potential use of HRCs in GMP processes.

One of the final goals of HRCs is to produce plant-expressed compounds of interest, ideally in large-scale bioreactors (Figure 2C). The use of bioreactors for HRCs has to be optimized according to the species and the molecules of interest. Some of the considerations for optimization are hairiness, thickness, length, and branching of the roots. Additionally, both metabolite production and cell growth are non-homogeneous according to 


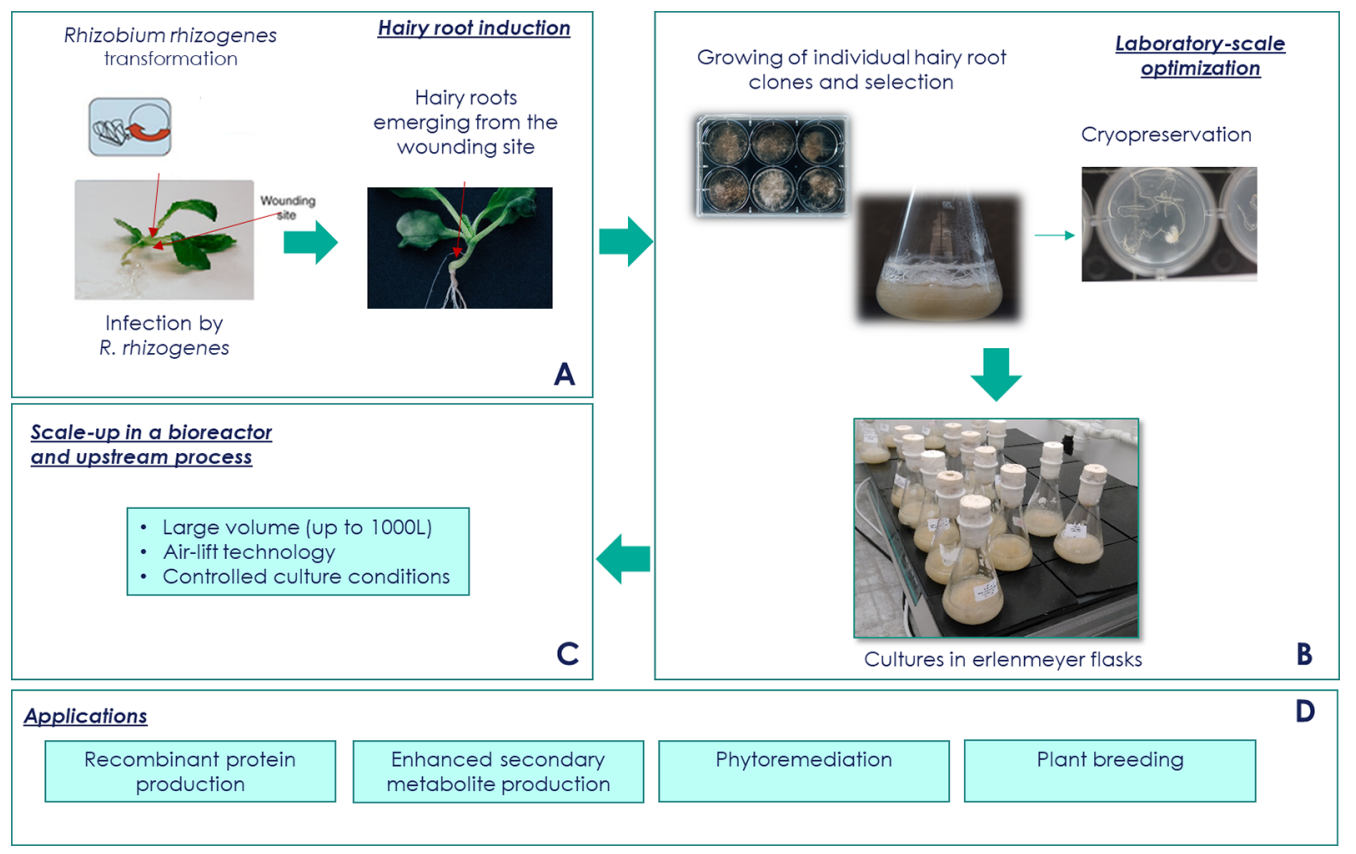

FIGURE 2 | Hairy root culture platform. (A) Hairy root culture (HRC) induction. The efficiency of transformation depends on different factors such as type of explant and age, and the strain and density of Rhizobium rhizogenes. Acetosyringone addition can help to permeate the cell walls and plant membranes promoting better infection efficiency. After infection, the use ofantibiotics to eliminate excess of bacteria is necessary. (B) Conservation and pre-bioreactor stage. Storage clones in master/working transgenic bank is possible using cryoconservation method. In another way, several strategies can be used to improve the yields of the desired compounds. Among these strategies, there is inoculum and nutrient medium optimization, elicitation, selection of high-producing lines, metabolic engineering approaches, permeabilization, and two-phase systems cultivation. (C) Bioreactor stage. Different conditions can be optimized according to the desired outcome. Some of the optimizable variables are bioreactor operation mode (batch, fed-batch), culture conditions (air flow rate, temperature), hardware configurations (drive wave reactor, pneumatically driven bubble column bioreactor, and gas-phase bed reactor also referred to as "mist bioreactor"). Another medium-scale up culture approach is the use of shaken flasks using orbital shaker with HRC grown in liquid medium. (D) Applications. Among the possible molecules derived from HRCs there are specialized metabolites and recombinant proteins. Transgenic HRs can also be used for phytoremediation or mechanism understanding.

the plant initially transformed and to the molecule to be produced, which further complicates bioreactor optimization (Doran, 2013; Lehmann et al., 2014). Moreover, monitoring the root growth is challenging due to the inability to obtain homogeneous HR samples on a real-time basis. Furthermore, doubling time is also a crucial factor to be considered to ensure that the HR growth occurs as expected. Despite all the above-mentioned constraints, when bioreactors can be developed, they are suitable for HRCs because of their self-containment with inflow and outflow systems for liquid and air, enabling a controlled growth in sterile environments that contain only liquid nutrients. Generally, conditions such as $\mathrm{pH}$, aeration, temperature, and dissolved gasses can be controlled in bioreactors (Doran, 2013).

The bioreactors used for HRCs can be classified into gasphase or liquid-phase reactors and are generally derived from classical bioreactors but adapted for the culture of plant tissues. Also a lot of studies have been conducted using disposable bioreactors e.g. wave-type of bioreactors (Eibl and Eibl, 2008; Eibl et al., 2011; Georgiev et al., 2013). In brief, in gas-phase reactors, roots are exposed to air and other gas mixtures, and nutrients are commonly distributed to the roots as droplets of different sizes. An example of this type of bioreactor is the mist and trickle-bed bioreactors (Georgiev et al., 2013; Srikantan and Srivastava, 2018). Such bioreactor generally offers abundant oxygen supply. On the other hand, in liquid-phase reactors, roots are submerged in the medium (explaining the given name of "submerged reactors"). Examples of liquid-phase reactors are stirred tank and airlift and bubble column reactors (Doran, 2013). The advantages of this type of bioreactors are the wellknown and simple design and construction, low risk of contamination, and low maintenance. Until now, most of the HRCs were grown in liquid-phase bioreactors with volume up to 20-30 L (Lee et al., 1999; Sivakumar et al., 2005; Georgiev et al., 2013). However, for some HRCs, volumes of several hundreds of liters have been reached (Wilson et al., 1990; Samabriva's internal data). The emergence of companies able to produce HRs in optimized and perfectly controlled, large volumes bioreactors, offer interesting perspectives for an industrial use of this biological material in the future.

Finally, the classical downstream process of any biosynthetic compound takes place after the production. The produced compound can be secreted into the media, facilitating the downstream processing. Nevertheless, some products may remain within the cells, thus potentially generating trouble for 
purification (Talano et al., 2012). It is interesting to note that sometimes non-natural or biosynthetically foreign compound can be more efficiently secreted to the culture medium than compounds which are naturally produced by the HRs. This was earlier shown by tobacco HRs overexpressing hyoscyamine-6 $\beta$ hydroxylase and secreting up to $85 \%$ of the produced scopolamine in the culture medium, in contrast to the Hyoscyamus HRs where the majority of the product was retained in intracellular space (Häkkinen et al., 2005). Other strategies enabling a permeabilization of HRs for an optimization of the targeted metabolite/recombinant protein release into the culture medium were also used. Several approaches were tested, most of the time involving treatment with organic solvents or surfactants (Chandra and Chandra, 2011).

The products being expressed by HRs can correspond to specialized metabolites, naturally produced by the plant, or recombinant, heterologous proteins. HRs can also serve as tools for the study of gene function, phytoremediation, molecular breeding, among others (Figure 2D).

\section{PRODUCTION OF RECOMBINANT PROTEINS}

To our knowledge, the first proof of concept for HRCs was achieved by producing a mouse monoclonal antibody in HRs of tobacco plants (Wongsamuth and Doran, 1997). By then, it was shown that this antibody was secreted and accumulated in the culture medium. Afterwards, other recombinant proteins have been produced and secreted by tobacco HRs, including for example the green fluorescent protein (GFP) (Medina-Bolívar and Cramer, 2004), human acetylcholinesterase (Woods et al., 2008), murine interleukin (Liu et al., 2009), thaumatin sweetener (Pham et al., 2012), human interferon alpha-2b (Luchakivskaia et al., 2012), recombinant human EPO (rhEPO) (Gurusamy et al., 2017), and recombinant alpha-L-iduronidase (Cardon et al., 2019). Even complex glycosylated proteins can be produced using HR platforms with highly homogeneous posttranslational profiles. As an example, Cardon et al. (2019) detailed, the $\mathrm{N}$ - and O-glycosylation profiles of a human lysosomal enzyme produced from HRC and showed that all Nglycosylation sites of this protein were occupied by paucimannose profiles with a very high homogeneity. Such paucimannosidic profile is of particular relevance for the production of proteins that could be used to treat patients with some lysosomal disorders (such as Gaucher disease or Fabry disease). Therefore, numerous heterologous proteins have been produced using HRs-based expression systems including antigens, antibodies, enzymes, and immunomodulators as described in Table $\mathbf{1}$.

The design of the construct used to express the recombinant protein is a critical step. Commonly, a construct contains a promoter, a signal peptide to orientate the heterologous proteins to the expected pathway (i.e. the secretory pathway), the gene encoding the protein of interest, and a polyadenylation sequence. Gene constructs are strategically designed to contain a strong promoter for high-level gene expression. The strong constitutive promoter cauliflower mosaic virus (CaMV35s) or its enhanced version (deCaMV35S) have been most commonly used to drive transgene expression in HRCs (Georgiev et al., 2012). Besides using the above-mentioned constitutive promoters, inducible promoters can also be used. For instance, glucocorticoid- or thermo-inducible promoters are used to drive controlled gene expression at required times in HRC systems (Sun and Peebles, 2016). Moreover, the use of enhancer like TMV omega enhancer could help to improve the productivity. Retention signals such as the well-known KDEL or HDEL sequences can be incorporated in the molecular construct in order to increase the cytoplasmic content of the heterologous protein. This strategy can be relevant to prevent protein degradation in the culture medium in some situations, thus enhancing the overall production yields. For example, the use of the KDEL sequence at the C-terminal end of the 14D9 antibody increases its accumulation level in tobacco HRCs (Chahardoli et al., 2018). On the other hand, when the goal is to target the expression of a foreign protein to the secretory pathway, a dedicated signal peptide such as the ER signal peptide cal ( $\mathrm{N}$-terminal calreticulin fusion sequence) can be incorporated in the molecular construction. To illustrate such strategy this signal peptide has appeared essential for the secretion of human erythropoietin into the medium of $N$. tabacum HRCs (Gurusamy et al., 2017).

$R$. rhizogenes mediated transformation can be applied, once the molecular construct has been designed, to introduce the heterologous gene of interest in the recipient plant without changing the genetic architecture of the plant host, enabling the transgenic HR to produce the respective heterologous protein. The most common strategy consists in modifying the $R$. rhizogenes strain by integrating a heterologous gene of interest into the bacteria via classical molecular biology methods before infecting the plant. In this case, standard plant expression binary vectors harboring specific T-DNA with the gene of interest are used. Using this strategy, stable integration of the gene(s) of interest is obtained. Due to the random insertion into the genome of the plant, it is necessary to identify the most robust clones among all generated clones in terms of productivity and growth capacity as illustrated by Huet et al. (2014). As described in Donini and Marusic (2018) a second strategy consists in directly infecting a transgenic plant already expressing the heterologous protein using the wild type strain of $R$. rhizogenes. Thus, no genetic engineering of the bacterial strain is required. In this respect, the availability of plant mutant banks offers a wide range of possibilities.

As mentioned above, the recombinant proteins can be either produced internally or secreted into the culture medium. Large proteins- can be secreted into the culture medium of HRC (Cardon et al., 2019), enabling a large spectrum of protein production (Table 1). As an example, alpha-L-iduronidase, a complex human protein of $72 \mathrm{kDa}$ is well-secreted into the culture medium once produced by HRCs (Cardon et al., 2019). Beyond $110 \mathrm{kDa}$, the secretion of the protein requires the use of particular strategies, such as a wall permeabilization if the protein remains bound to the biomass (e.g. using DMSO) 
TABLE 1 | Examples of recombinant proteins produced using hairy root cultures (HRCs)

\begin{tabular}{|c|c|c|c|c|}
\hline $\begin{array}{l}\text { Recombinant } \\
\text { protein }\end{array}$ & $\begin{array}{c}\text { Plant } \\
\text { species }\end{array}$ & Protein function & $\begin{array}{l}\text { Culture } \\
\text { approach }\end{array}$ & Reference \\
\hline $\begin{array}{l}\text { Monoclonal } \\
\text { antibody M12 }\end{array}$ & $\begin{array}{l}\text { Nicotiana } \\
\text { tabacum }\end{array}$ & Anti-cancer & $\begin{array}{l}\text { Shake } \\
\text { flasks }\end{array}$ & $\begin{array}{l}\text { (Häkkinen } \\
\text { et al., 2014) }\end{array}$ \\
\hline $\begin{array}{l}\text { Green } \\
\text { fluorescent } \\
\text { protein (GFP) }\end{array}$ & $\begin{array}{l}\text { Brassica } \\
\text { rapa }\end{array}$ & Reporter protein & $\begin{array}{l}\text { Shake } \\
\text { flasks }\end{array}$ & $\begin{array}{l}\text { (Huet et al., } \\
\text { 2014) }\end{array}$ \\
\hline $\begin{array}{l}\text { Human tissue } \\
\text { plasminogen } \\
\text { activator (t-PA) }\end{array}$ & $\begin{array}{l}\text { Cucumis } \\
\text { melo }\end{array}$ & $\begin{array}{l}\text { Thrombolytic } \\
\text { protein that } \\
\text { converts } \\
\text { plasminogen into } \\
\text { plasmin }\end{array}$ & $\begin{array}{l}\text { Shake } \\
\text { flasks }\end{array}$ & $\begin{array}{l}\text { (Abdoli } \\
\text { Nasab et al., } \\
\text { 2016) }\end{array}$ \\
\hline MAP30 & $\begin{array}{l}\text { Nicotiana } \\
\text { tabacum }\end{array}$ & $\begin{array}{l}\text { Anti-tumor and } \\
\text { anti-HIV protein }\end{array}$ & $\begin{array}{l}\text { Shake } \\
\text { flasks }\end{array}$ & $\begin{array}{l}\text { (Moghadam } \\
\text { et al., 2016) }\end{array}$ \\
\hline $\begin{array}{l}\text { Tumor- } \\
\text { targeting } \\
\text { monoclonal } \\
\text { antibody mAb } \\
\text { H10 }\end{array}$ & $\begin{array}{l}\text { Nicotiana } \\
\text { benthamiana }\end{array}$ & Anti-cancer & $\begin{array}{l}\text { Shake } \\
\text { flasks }\end{array}$ & $\begin{array}{l}\text { (Lonoce } \\
\text { et al., 2016) }\end{array}$ \\
\hline $\begin{array}{l}\text { Human gastric } \\
\text { lipase }\end{array}$ & $\begin{array}{l}\text { Brassica } \\
\text { rapa }\end{array}$ & $\begin{array}{l}\text { Therapeutic } \\
\text { enzyme used for } \\
\text { pancreatic enzyme } \\
\text { deficiency, it } \\
\text { contributes to fatty } \\
\text { acid release from } \\
\text { ingested } \\
\text { triglycerides. }\end{array}$ & $\begin{array}{l}\text { Shake } \\
\text { flasks }\end{array}$ & $\begin{array}{l}\text { (Ele Ekouna } \\
\text { et al., 2017) }\end{array}$ \\
\hline $\begin{array}{l}\text { Recombinant } \\
\text { human EPO } \\
\text { (rhEPO) }\end{array}$ & $\begin{array}{l}\text { Nicotiana } \\
\text { tabacum }\end{array}$ & $\begin{array}{l}\text { Glycoprotein } \\
\text { hormone that } \\
\text { influences the } \\
\text { production of } \\
\text { erythrocytes } \\
\text { through } \\
\text { erythropoiesis. } \\
\text { EPO is used for } \\
\text { the treatment of } \\
\text { anemia. }\end{array}$ & $\begin{array}{l}\text { Shake } \\
\text { flasks }\end{array}$ & $\begin{array}{l}\text { (Gurusamy } \\
\text { et al., 2017) }\end{array}$ \\
\hline $\begin{array}{l}\text { Virus like } \\
\text { particle } \\
\text { harboring } \\
\text { recombinant } \\
\text { protein shells } \\
\text { of Johnson } \\
\text { grass chlorotic } \\
\text { stripe mosaic } \\
\text { virus }\end{array}$ & $\begin{array}{l}\text { Nicotiana } \\
\text { tabacum }\end{array}$ & Vaccine & $\begin{array}{l}\text { Shake } \\
\text { flasks }\end{array}$ & $\begin{array}{l}\text { (Alemzadeh } \\
\text { et al., 2017) }\end{array}$ \\
\hline $\begin{array}{l}\text { Anti-CD20 } \\
\text { scFv-Fc } \\
\text { antibody }\end{array}$ & $\begin{array}{l}\text { Nicotiana } \\
\text { benthamiana }\end{array}$ & $\begin{array}{l}\text { Tumor targeting } \\
\text { antibody }\end{array}$ & $\begin{array}{l}\text { Shake } \\
\text { flasks }\end{array}$ & $\begin{array}{l}\text { (Lonoce } \\
\text { et al., 2019) }\end{array}$ \\
\hline $\begin{array}{l}\text { Alpha-L- } \\
\text { iduronidase } \\
\text { (IDUA) }\end{array}$ & $\begin{array}{l}\text { Brassica } \\
\text { rapa }\end{array}$ & $\begin{array}{l}\text { Lysosomal } \\
\text { enzyme which } \\
\text { catalyzes the } \\
\text { hydrolysis of } \\
\text { unsulfated alpha- } \\
\text { L-iduronosidic } \\
\text { linkages in } \\
\text { dermatan sulfate }\end{array}$ & Bioreactors & $\begin{array}{l}\text { (Cardon } \\
\text { et al., 2019) }\end{array}$ \\
\hline
\end{tabular}

(Talano et al., 2012). Moreover, the physicochemical characteristics of the proteins such as hydrophobicity and charge can also be important determinants for secretion and/or retention. The use of protein-stabilizing agents in the plant culture medium also represents a promising method for a stable maintenance of the productivity. Examples of protein stabilizers and protease inhibitors that can be employed are bovine serum albumin (BSA) (for protein-based stabilization), gelatine, PEG, PVP, and other polymers (to protect proteins from plant cell denaturing agents), and mannitol (to regulate osmotic pressure of the medium thus minimizing cell lysis) (Alvarez and Alvarez, 2014).

In summary, all steps of the process have to be carefully designed when producing recombinant proteins in HRCs, from the selection of the starting plant material to the molecular strategy considering not only the particularities of the heterologous gene structure itself but also its future features according to the source from where it will be purified. By meeting those criteria, the production of functional proteins within expected productivities is more likely to occur.

\section{PRODUCTION OF SPECIALIZED METABOLITES}

For the production of specialized metabolites, HRCs are more appropriate than cell or callus cultures due to characteristics such as genetic stability, high biomass production, and efficient biosynthetic capacity. Moreover, HRCs are able to produce specialized metabolites for a long period of time (Peebles et al., 2009; Häkkinen et al., 2016). Specialized metabolites are usually produced using non-transgenic HRCs. In this case, the plants selected are those species which naturally produce the compound of interest. Some examples of specialized metabolites already produced in wild-type HRCs are azadirachtin (biopesticide) (Thakore and Srivastava, 2017), betalain (red pigments for food industry) (Pavlov et al., 2005), camptothecin (antitumor agent in the treatment of ovarian and colorectal cancers treatment) (Wetterauer et al., 2018), and whitanolide A (brain regenerative compound) (Shajahan et al., 2017). A transgene can also be introduced in wild type HRs in order to increase the amount of a particular specialized metabolite (Jouhikainen et al., 1999; Moyano et al., 2003; Zhang et al., 2004; Ritala et al., 2014). As an example, gene silencing knock-out strategies have been used either to avoid negative regulation or to modify a biosynthetic pathway, therefore improving the production of specific compounds (Mehrotra et al., 2015). In this last case, the over- or co-expression of enzymes involved in the biosynthesis pathway may be instrumental in the production of high-value metabolites. Some examples of specialized metabolites produced using transgenic HRCs are tropane alkaloids such as scopolamine and hyoscyamine (Jouhikainen et al., 1999; Häkkinen et al., 2016; Guo et al., 2018; Khezerluo et al., 2018), catharanthine (Hu, 2006), ginsenosides (Woo et al., 2004), solanoside (Putalun et al., 2004), and vitamin C (Wevar Oller et al., 2009). Sirikantaramas and Taura (2017), utilizing transgenic HRCs and substrate feeding, were able to produce cannabinoids in N. tabacum, even if this species is normally not able to produce such specialized metabolite. A recent review describes some examples of valuable metabolites produced in transgenic HRs and their associated strategies, e.g. the concept of phytoremediation (Doran, 2009; Vaghari et al., 2017). 
Regardless of the strategy (i.e. use of transgenic or nontransgenic HRCs), the production of specialized metabolites has been successfully improved by optimizing the growth conditions (e.g. carbon source, aeration, $\mathrm{pH}$, light/dark, culture medium composition), selection of the clone (Sevón et al., 1998), and/or by paying a particular attention to the selection of adapted elicitors (Wang and Wu, 2013; Perassolo et al., 2017; Halder et al., 2018). The expression of specialized metabolites in HRCs, as in all plant-based production systems, requires the identification of the most appropriate elicitors and administration scheme. There is substantial literature exemplifying the elicitors that can be used to produce specialized metabolites using in vitro plant tissue culture systems (Zhou and Wu, 2006; Ramakrishna and Ravishankar, 2011; Hussain et al., 2012; Murthy et al., 2014; O'Kennedy et al., 2016). Not all of these elicitors were tested in HRCs and only a few of the most representative examples have been selected in this document to illustrate the current trend in the use of elicitors (see Table 2). Table 2, although not exhaustive, highlights the great diversity of elicitors available. However, a thorough analysis of all elicitors used in the literature shows that some candidates have been more frequently used and/or successfully tested. These include methyl-jasmonate, jasmonic acid, chitosan, or salicylic acid. The ability of an elicitor to induce a metabolic pathway is dependent on the plant and on the metabolite of interest. Also the ability of certain elicitors to affect the secretion of the metabolite has to be considered (Bais et al., 2003; Thimmaraju et al., 2003). The recognition of elicitors by the plants seems to be carried out by specific receptors on the surface of the plant cell or at the intracellular level allowing the triggering of a signal transduction cascade leading to the stimulation of the cells, a characteristic set of plant defense responses (Nürnberger, 1999).

Various studies have also shown that there is a synergistic effect between several elicitors. This is the case, for example, with the cross-use of biotic and abiotic elicitors, which makes possible to increase the production of tanshinones in Salvia miltiorrhiza HRC (Yan et al., 2006). The increase in productivity can be moderate: 4.5fold for the production of isoflavonoid in Pueraria candollei HRCs after elicitation by the yeast extract (Udomsuk et al., 2011), or can be significant as stilbenes excretion increased by 570 -fold after the elicitation with MeJA and methyl- $\beta$-cyclodextrins in Vitis vinifera HRs (Tisserant et al., 2016). Moreover, beyond the type of elicitor, its dosage (not too strong to avoid toxicity nor too low to generate an effect), its exposure time, and the plant material and the age to which it is applied are of particular relevance.

A recently used approach for the optimization of specialized metabolites through HRCs is in silico modeling (e.g. fuzzy logicbased simulations, neural network). This type of computer modeling approaches has been used to optimize chemical culture conditions of HRCs (Lenk et al., 2014).

\section{CONCLUSIONS AND FUTURE PERSPECTIVES}

In theory, HRCs can be induced from basically all plant species. Therefore, this technology could potentially be implemented to rare, valuable, threatened, or endemic medicinal species in an
TABLE 2 | Examples of specialized metabolites produced by HRCs and examples of elicitors used.

\begin{tabular}{|c|c|c|c|}
\hline Plant species & Products & Elicitors & References \\
\hline Ammi majus & $\mathrm{BION}_{\circledast}$ & $\begin{array}{l}\text { Coumarine/ } \\
\text { Furocoumarine }\end{array}$ & $\begin{array}{l}\text { (Staniszewska } \\
\text { et al., 2003) }\end{array}$ \\
\hline Arachis & Resveratrol, & Cyclodextrin & (Yang et al., 2015) \\
\hline hypogaea & $\begin{array}{l}\text { Piceatannol, } \\
\text { Arachidin-1, and } \\
\text { Arachidin-3 }\end{array}$ & & \\
\hline $\begin{array}{l}\text { Astragalus } \\
\text { membranaceus }\end{array}$ & Isoflavonoid & Methyl jasmonate & (Gai et al., 2016) \\
\hline $\begin{array}{l}\text { Brugmansia } \\
\text { candida }\end{array}$ & Hyoscyamine & $\mathrm{CdCl}_{2}$ & $\begin{array}{l}\text { (Pitta-Alvarez } \\
\text { et al., 2000) }\end{array}$ \\
\hline $\begin{array}{l}\text { Chicorium } \\
\text { intybus }\end{array}$ & Esculin/Esculetin & $\begin{array}{l}\text { Phytopthora } \\
\text { parasitica filtrate }\end{array}$ & (Bais et al., 2000) \\
\hline $\begin{array}{l}\text { Echinacea } \\
\text { pupurea }\end{array}$ & Caffeic & Gibberellic acid & $\begin{array}{l}\text { (Abbasi et al., } \\
\text { 2012) }\end{array}$ \\
\hline $\begin{array}{l}\text { Fagopyrum } \\
\text { tataricum }\end{array}$ & Rutin, quercetin & UV-B & $\begin{array}{l}\text { (Huang et al., } \\
\text { 2016) }\end{array}$ \\
\hline $\begin{array}{l}\text { Hyoscyamus } \\
\text { muticus }\end{array}$ & Tropane alkaloids & Chitosan & $\begin{array}{l}\text { (Sevón et al., } \\
\text { 1992) }\end{array}$ \\
\hline Panax ginseng & Ginsenoside & Methyl jasmonate & $\begin{array}{l}\text { (Palazón et al., } \\
\text { 2003) }\end{array}$ \\
\hline Papavar orientale & Morphine & Methyl jasmonate & $\begin{array}{l}\text { (Hashemi and } \\
\text { Naghavi, 2016) }\end{array}$ \\
\hline Plumbago indica & Plumbagin & Jasmonic acid & $\begin{array}{l}\text { (Gangopadhyay } \\
\text { et al., 2011) }\end{array}$ \\
\hline $\begin{array}{l}\text { Psoralea } \\
\text { corylifolia }\end{array}$ & Daidzin & Jasmonate & $\begin{array}{l}\text { (Zaheer et al., } \\
\text { 2016) }\end{array}$ \\
\hline Salvia castanea & Tanshinone & Methyl jasmonate & (Li et al., 2016) \\
\hline $\begin{array}{l}\text { Salvia } \\
\text { miltiorrhiza, }\end{array}$ & Tanshinone & Salicylic acid & (Hao et al., 2015) \\
\hline $\begin{array}{l}\text { Scopolia } \\
\text { parviflora }\end{array}$ & Scopolamine & Bacteria sp. & (Jung et al., 2003) \\
\hline $\begin{array}{l}\text { Solanum } \\
\text { khasianum }\end{array}$ & Alkaloids & $\begin{array}{l}\text { Aspergillus niger, } \\
\text { cellulase }\end{array}$ & $\begin{array}{l}\text { (Srivastava et al., } \\
\text { 2016) }\end{array}$ \\
\hline
\end{tabular}

effort to preserve biodiversity. Moreover, HRCs have become important tools for studying biosynthesis of plant-derived molecules and they are appealing bioproduction systems with different advantages over cell suspensions and open-field-grown plants. HRCs are also very optimal model systems for recombinant protein/specialized metabolite production, or for unraveling the intricate interactions implicated in phytoremediation.

Using recent molecular biology tools, it is now possible to develop high producing clones that are able to secrete improved functional and efficient molecules for different industrial applications (food, cosmetic, or pharmaceuticals). Thus, the current state of the HRC technology should have an impact on broad commercialization of HRCs, given their several applications. This increasing interest for HRC requires developing robust cost effective GMP ready process with well-controlled systems.

Moreover, the new molecular biology tools (e.g. the CRISPR/ Cas9 technology) allow a strong perspective for development of HRCs. According with PubMed Central database, the first transformation of HRs using CRISPR/Cas9 strategy has been effective in 2014, when transgenic tomato HRs producing eGFP were published (Ron et al., 2014). CRISPR/Cas9 has been used as a tool to study and optimize the mutagenesis processes in HRs of soybean (Glycine max) and Medicago truncatula (Michno et al., 2015; Du et al., 2016) and more recently for the knock-out of a 
gene involved in HRs architecture (BcFLA1) in Brassica carinata (Kirchner et al., 2017). The possibility to generate HR clones harboring knock-out gene(s) will facilitate metabolic pathway understanding or modification. This kind of experimentation can be used to reinforce specialized metabolites expression, to modify posttranslational modifications of recombinant proteins, e.g. glycosylation features or to help in the elucidation of biosynthetic pathways.

Due to an initial poor productivity and a scale-up issue, HRCs were, until now, not used at an industrial level except in the cosmetic area where an extract from a basil HRC is commercialized to treat hair loss. The strong optimization of the process in terms of production capacity, bioreactor size, and ability to modify HRCs to produce tailored-made complex molecules pave the way to a prominent place as a future biotechnology tool of this technology in plant molecular farming.

\section{REFERENCES}

Abbasi, B. H., Stiles, A. R., Saxena, P. K., and Liu, C. Z. (2012). Gibberellic acid increases secondary metabolite production in Echinacea purpurea hairy roots. Appl. Biochem. Biotechnol. 168, 2057-2066. doi: 10.1007/s12010-012-9917-z

Abdoli Nasab, M., Jalali Javaran, M., Cusido, R. M., and Palazon, J. (2016). Purification of recombinant tissue plasminogen activator (rtPA) protein from transplastomic tobacco plants. Plant Physiol. Biochem. 108, 139-144. doi: 10.1016/j.plaphy.2016.06.029

Alemzadeh, E., Izadpanah, K., and Ahmadi, F. (2017). Generation of recombinant protein shells of Johnson grass chlorotic stripe mosaic virus in tobacco plants and their use as drug carrier. J. Virol. Methods 248, 148-153. doi: 10.1016/ j.jviromet.2017.07.003

Alvarez, M. A., and Alvarez, M. A. (2014). "The Antibody 14D9 as an experimental model for molecular farming chapter 7," in Plant Biotechnology for Health (Cham: Springer International Publishing), 111-131. doi: 10.1007/ 978-3-319-05771-2_7

Bais, H. P., Govindaswamy, S., and Ravishankar, G. A. (2000). Enhancement of growth and coumarin production in hairy root cultures of witloof chicory (Cichorium intybus L.cv.Lucknow local) under the influence of fungal elicitors. J. Biosci. Bioeng. 90, 648-653. doi: 10.1016/\$1389-1723(00)90011-2

Bais, H. P., Vepachedu, R., and Vivanco, J. M. (2003). Root specific elicitation and exudation of fluorescent $\beta$-carbolines in transformed root cultures of Oxalis tuberosa. Plant Physiol. Biochem. 41, 345-353. doi: 10.1016/S0981-9428(03) 00029-9

Bulgakov, V. P., Veremeichik, G. N., and Shkryl, Y. N. (2015). The rolB gene activates the expression of genes encoding microRNA processing machinery. Biotechnol. Lett. 37, 921-925. doi: 10.1007/s10529-014-1743-7

Bulgakov, V. P., Veremeichik, G. N., Grigorchuk, V. P., Rybin, V. G., and Shkryl, Y. N. (2016). The rolB gene activates secondary metabolism in Arabidopsis calli via selective activation of genes encoding MYB and bHLH transcription factors. Plant Physiol. Biochem. 102, 70-79. doi: 10.1016/j.plaphy.2016.02.015

Bulgakov, V. P., Vereshchagina, Y. V., Bulgakov, D. V., Veremeichik, G. N., and Shkryl, Y. N. (2018). The rolB plant oncogene affects multiple signaling protein modules related to hormone signaling and plant defense. Sci. Rep. 8, 1-14. doi: 10.1038/s41598-018-20694-6

Bulgakov, V. P. (2008). Functions of rol genes in plant secondary metabolism. Biotechnol. -Adv. 26, 318-324. doi: 10.1016/j.biotechadv.2008.03.001

Cardon, F., Pallisse, R., Bardor, M., Caron, A., Vanier, J., Ele Ekouna, J. P., et al. (2019). Brassica rapa hairy root based expression system leads to the production of highly homogenous and reproducible profiles of recombinant human alpha-Liduronidase. Plant Biotechnol. J. 17, 505-516. doi: 10.1111/pbi.12994

Chahardoli, M., Fazeli, A., and Ghabooli, M. (2018). Recombinant production of bovine Lactoferrin-derived antimicrobial peptide in tobacco hairy roots expression system. Plant Physiol. Biochem. 123, 414-421. doi: 10.1016/ j.plaphy.2017.12.037

\section{AUTHOR CONTRIBUTIONS}

FC and AR conceived the idea of this review and designed the overall concept. FC and NGV were the most involved in the writing. $\mathrm{SH}, \mathrm{CL}, \mathrm{MG}, \mathrm{KMOC}$, and AR also participated in the writing of the review and/or reviewed it. All authors approved the final version.

\section{FUNDING}

This review was partly supported by the European Union's Horizon 2020 Research and Innovation Program (PharmaFactory project under grant agreement No 774078).

Chandra, S., and Chandra, R. (2011). Engineering secondary metabolite production in hairy roots. Phytochem. Rev. 10, 371. doi: 10.1007/s11101-0119210-8

Chandra, S. (2012). Natural plant genetic engineer Agrobacterium rhizogenes: Role of T-DNA in plant secondary metabolism. Biotechnol. Lett. 34, 407-415. doi: 10.1007/s10529-011-0785-3

Chilton, M. D., Tepfer, D. A., Petit, A., David, C., Casse Delbart, F., and Tempé, J. (1982). Agrobacterium rhizogenes inserts T-DNA into the genomes of the host plant root cells. Nature 295, 432-434. doi: 10.1038/295432a0

De Meijer, E. P. M., Bagatta, M., Carboni, A., Crucitti, P., Moliterni, V. M. C., Ranalli, P., et al. (2003). The inheritance of chemical phenotype in Cannabis sativa L. Genetics 163, 335-346.

Donini, M., and Marusic, C. (2018). "Hairy Roots as Bioreactors for the Production of Biopharmaceuticals," in Hairy Roots An Effective Tool of Plant Biotechnology (Singapore: Springer Singapore), 213-225. doi: 10.1007/978981-13-2562-5 9

Doran, P. M. (1997). Hairy roots : culture and applications (Amsterdam: Harwood Academic Publishers).

Doran, P. M. (2009). Application of plant tissue cultures in phytoremediation research: incentives and limitations. Biotechnol. Bioeng. 103, 60-76. doi: 10.1002/bit.22280

Doran, P. M. (2013). Biotechnology of hairy root systems. Adv. Biochem. Eng. Biotechnol. 134, 91-114. doi: 10.1007/978-3-642-39019-7

Du, H., Zeng, X., Zhao, M., Cui, X., Wang, Q., Yang, H., et al. (2016). Efficient targeted mutagenesis in soybean by TALENs and CRISPR/Cas9. J. Biotechnol. 217, 90-97. doi: 10.1016/j.jbiotec.2015.11.005

Eibl, R., and Eibl, D. (2008). Design of bioreactors suitable for plant cell and tissue cultures. Phytochem. Rev. 7, 593-598. doi: 10.1007/s11101-007-9083-z

Eibl, D., Peuker, T., and Eibl, R. (2011). "Single-Use equipment in Biopharmaceutical Manufacture: A brief introduction," in Single-Use Technology in Biopharmaceutical Manufacture (Hoboken, NJ, USA: John Wiley \& Sons, Inc.), 1-11. doi: 10.1002/9780470909997.ch1

Ele Ekouna, J.-P., Boitel-Conti, M., Lerouge, P., Bardor, M., and Guerineau, F. (2017). Enhanced production of recombinant human gastric lipase in turnip hairy roots. Plant Cell Tissue Organ Cult. 131, 601-610. doi: 10.1007/s11240017-1309-1

Gai, Q. Y., Jiao, J., Luo, M., Wang, W., Gu, C. B., Fu, Y. J., et al. (2016). Tremendous enhancements of isoflavonoid biosynthesis, associated gene expression and antioxidant capacity in Astragalus membranaceus hairy root cultures elicited by methyl jasmonate. Process Biochem. 51, 642-649. doi: 10.1016/j.procbio.2016.01.012

Gangopadhyay, M., Dewanjee, S., and Bhattacharya, S. (2011). Enhanced plumbagin production in elicited Plumbago indica hairy root cultures. J. Biosci. Bioeng. 111, 706-710. doi: 10.1016/j.jbiosc.2011.02.003

Gelvin, S. B. (2009). Agrobacterium in the genomics age. Plant Physiol. 150, 1665 1676. doi: $10.1104 / p p .109 .139873$ 
Georgiev, M. I., Agostini, E., Ludwig-Müller, J., and Xu, J. (2012). Genetically transformed roots: from plant disease to biotechnological resource. Trends Biotechnol. 30, 528-537. doi: 10.1016/j.tibtech.2012.07.001

Georgiev, M. I., Eibl, R., and Zhong, J. J. (2013). Hosting the plant cells in vitro: Recent trends in bioreactors. Appl. Microbiol. Biotechnol. 97, 3787-3800. doi: 10.1007/s00253-013-4817-x

Georgiev, M. I., Radziszewska, A., Neumann, M., Marchev, A., Alipieva, K., and Ludwig-Müller, J. (2015). Metabolic alterations of Verbascum nigrum L. plants and SAArT transformed roots as revealed by NMR-based metabolomics. Plant Cell Tissue Organ Cult. 123, 349-356. doi: 10.1007/s11240-015-0840-1

Guillon, S., Trémouillaux-Guiller, J., Pati, P. K., Rideau, M., and Gantet, P. (2006). Harnessing the potential of hairy roots: dawn of a new era. Trends Biotechnol. 24, 403-409. doi: 10.1016/j.tibtech.2006.07.002

Guo, Z., Tan, H., Lv, Z., Ji, Q., Huang, Y., Liu, J., et al. (2018). Targeted expression of Vitreoscilla hemoglobin improves the production of tropane alkaloids in Hyoscyamus niger hairy roots. Sci. Rep. 8, 1-12. doi: 10.1038/s41598-018-36156-y

Gurusamy, P. D., Schäfer, H., Ramamoorthy, S., and Wink, M. (2017). Biologically active recombinant human erythropoietin expressed in hairy root cultures and regenerated plantlets of Nicotiana tabacum L. PloS One 12 (8), e0182367. doi: 10.1371/journal.pone.0182367

Häkkinen, S. T., and Oksman-Caldentey, K.-M. (2018). "Progress and prospects of hairy root research," in Hairy Roots: An Effective Tool of Plant Biotechnology. Eds. V. Srivastava, S. Mehrotra and S. Mishra (Singapore: Springer), 3-19. doi: 10.1007/978-981-13-2562-5

Häkkinen, S. T., and Ritala, A. (2010). Medicinal compounds produced in plant cell factories Medicinal plant biotechnology. Ed. R. Arora (Oxfordshire, U. K.: CABI Publishing), 13-35. doi: 10.1079/9781845936785.0013

Häkkinen, S. T., Moyano, E., Cusidó, R. M., Palazó, J., Teresa, M., Ol, P., et al. (2005). Enhanced secretion of tropane alkaloids in Nicotiana tabacum hairy roots expressing heterologous hyoscyamine-6b-hydroxylase. doi: 10.1093/jxb/eri253

Häkkinen, S. T., Raven, N., Henquet, M., Laukkanen, M.-L., Anderlei, T., Pitkänen, J.-P., et al. (2014). Molecular farming in tobacco hairy roots by triggering the secretion of a pharmaceutical antibody. Biotechnol. Bioeng. 111, 336-346. doi: 10.1002/bit.25113

Häkkinen, S. T., Moyano, E., Cusidó, R. M., and Oksman-Caldentey, K.-M. (2016). Exploring the metabolic stability of engineered hairy roots after 16 years maintenance. Front. Plant Sci. 7, 1486. doi: 10.3389/fpls.2016.01486

Halder, M., Roychowdhury, D., and Jha, S. (2018). "A critical review on biotechnological interventions for production and yield enhancement of secondary metabolites in hairy root cultures," in Hairy Roots: An Effective Tool of Plant Biotechnology. Eds. V. Srivastava, S. Mehrotra and S. Mishra (Singapore: Springer), 21-44. doi: 10.1007/978-981-13-2562-5_2

Hao, X., Shi, M., Cui, L., Xu, C., Zhang, Y., and Kai, G. (2015). Effects of methyl jasmonate and salicylic acid on tanshinone production and biosynthetic gene expression in transgenic Salvia miltiorrhiza hairy roots. Biotechnol. Appl. Biochem. 62, 24-31. doi: 10.1002/bab.1236

Hashemi, S. M., and Naghavi, M. R. (2016). Production and gene expression of morphinan alkaloids in hairy root culture of Papaver orientale L. using abiotic elicitors. Plant Cell Tissue Organ Cult. 125, 31-41. doi: 10.1007/s11240-015-0927-8

Hirata, K., Goda, S., Phunchindawan, M., Du, D., Ishio, M., Sakai, A., et al. (1998). Cryopreservation of horseradish hairy root cultures by encapsulation- dehydration. J. Ferment. Bioeng. 86, 418-420. doi: 10.1016/S0922-338X(99)89017-5

$\mathrm{Hu}, \mathrm{H}$. (2006). A northern sky survey for both $\mathrm{TeV}$ cosmic-ray anisotropy and $\mathrm{TeV} \gamma$-ray sources using the Tibet air shower array. Nucl. Phys. B Proc. Suppl. 151, 121-124. doi: 10.1111/j.1744-7909.2006.00121.x

Huang, X., Yao, J., Zhao, Y., Xie, D., Jiang, X., and Xu, Z. (2016). Efficient rutin and quercetin biosynthesis through flavonoids-related gene expression in Fagopyrum tataricum gaertn. hairy root cultures with UV-B irradiation. Front. Plant Sci. 7, 63. doi: 10.3389/fpls.2016.00063

Huet, Y., Ele, J.-P., Aurore, E., Katiba, C., Michèle Boitel-Conti, M., and Guerineau, F. (2014). Production and secretion of a heterologous protein by turnip hairy roots with superiority over tobacco hairy roots. Biotechnol. Lett. 36, 181-190. doi: 10.1007/s10529-013-1335-y

Hussain, M. S., Fareed, S., Ansari, S., Rahman, M. A., Ahmad, I. Z., and Saeed, M. (2012). Current approaches toward production of secondary plant metabolites. J. Pharm. Bioallied Sci. 4, 10-20. doi: 10.4103/0975-7406.92725
Jost, W., Knappenberger, M., Claussnitzer, D., and Schaaf, A. (2014). Inventors; Greenovation Biotech GMBH, assignee. Method for increasing the secretion of recombinant proteins. AU2013248312; JP6215305; MX353243; US9850513.

Jouhikainen, K., Lindgren, L., Jokelainen, T., Hiltunen, R., Teeri, T. H., and Oksman-Caldentey, K.-M. (1999). Enhancement of scopolamine production in Hyoscyamus muticus L. hairy root cultures by genetic engineering. Planta 208, 545-551. doi: 10.1007/s004250050592

Jung, H.-Y., Kang, S.-M., Kang, Y.-M., Kang, M.-J., Yun, D.-J., Bahk, J.-D., et al. (2003). Enhanced production of scopolamine by bacterial elicitors in adventitious hairy root cultures of Scopolia parviflora. Enzyme Microb. Technol. 33, 987-990. doi: 10.1016/S0141-0229(03)00253-9

Khezerluo, M., Hosseini, B., and Amiri, J. (2018). Sodium nitroprusside stimulated production of tropane alkaloids and antioxidant enzymes activity in hairy root culture of Hyoscyamus reticulatus L. Acta Biol. Hung. 69, 437-448. doi: 10.1556/018.69.2018.4.6

Kirchner, T. W., Niehaus, M., Debener, T., Schenk, M. K., and Herde, M. (2017). Efficient generation of mutations mediated by CRISPR/Cas9 in the hairy root transformation system of Brassica carinata. PloS One 12 (9), e0185429. doi: 10.1371/journal.pone.0185429

Lambert, E., Goossens, A., Panis, B., Van Labeke, M. C., and Geelen, D. (2009). Cryopreservation of hairy root cultures of Maesa lanceolata and Medicago truncatula. Plant Cell Tissue Organ Cult. 96, 289-296. doi: 10.1007/s11240008-9486-6

Lee, K.-T., Suzuki, T., Yamakawa, T., Kodama, T., Igarashi, Y., and Shimomura, K. (1999). Production of tropane alkaloids by transformed root cultures of Atropa belladonna in stirred bioreactors with a stainless steel net. Plant Cell Rep. 18, 567-571. doi: 10.1007/s002990050623

Lehmann, N., Dittler, I., Lämsä, M., Ritala, A., Rischer, H., Eibl, D., et al. (2014). "Disposable bioreactors for cultivation of plant cell cultures," in Production of Biomass and Bioactive Compounds Using Bioreactor Technology (Dordrecht: Springer Netherlands), 17-46. doi: 10.1007/978-94-017-9223-3_2

Lenk, F., Sürmann, A., Oberthür, P., Schneider, M., Steingroewer, J., and Bley, T. (2014). Modeling hairy root tissue growth in in vitro environments using an agent-based, structured growth model. Bioprocess Biosyst. Eng. 37, 1173-1184. doi: 10.1007/s00449-013-1088-y

Li, B., Wang, B., Li, H., Peng, L., Ru, M., Liang, Z., et al. (2016). Establishment of Salvia castanea Diels f. tomentosa Stib. hairy root cultures and the promotion of tanshinone accumulation and gene expression with $\mathrm{Ag}+$, methyl jasmonate, and yeast extract elicitation. Protoplasma 253, 87-100. doi: 10.1007/s00709015-0790-9

Liu, C., Towler, M. J., Medrano, G., Cramer, C. L., and Weathers, P. J. (2009). Production of mouse interleukin-12 is greater in tobacco hairy roots grown in a mist reactor than in an airlift reactor. Biotechnol. Bioeng. 102, 1074-1086. doi: 10.1002/bit.22154

Lonoce, C., Salem, R., Marusic, C., Jutras, P. V., Scaloni, A., Salzano, A. M., et al. (2016). Production of a tumour-targeting antibody with a human-compatible glycosylation profile in N. benthamiana hairy root cultures. Biotechnol. J. 11, 1209-1220. doi: 10.1002/biot.201500628

Lonoce, C., Marusic, C., Morrocchi, E., Salzano, A. M., Scaloni, A., Novelli, F., et al. (2019). Enhancing the secretion of a glyco-engineered anti-CD20 scFv-Fc antibody in hairy root cultures. Biotechnol. J. 14, 1800081. doi: 10.1002/ biot.201800081

Luchakivskaia, I. S., Olevinskaia, Z. M., Kishchenko, E. M., Spivak, N. I., and Kuchuk, N. V (2012). Obtaining of hairy-root, callus and suspension carrot culture (Daucus carota L.) able to accumulate human interferon alpha-2b. Tsitol. Genet. 46, 18-26. doi: 10.3103/S0095452712010057

Mauro, M. L., Costantino, P., and Bettini, P. P. (2017). The never ending story of rol genes: a century after. Plant Cell Tissue Organ Cult. 131, 201-212. doi: $10.1007 /$ s11240-017-1277-5

Medina-Bolívar, F., and Cramer, C. (2004). "Production of Recombinant Proteins by Hairy Roots Cultured in Plastic Sleeve Bioreactors," in Recombinant Gene Expression (New Jersey: Humana Press), 351-364. doi: 10.1385/1-59259-774-2:351

Medina-Bolivar, L. F., and Yang, T. (2017). Inventors; Arkansas State University Jonesboro; assignee. method to increase the yield of products in plant material. EP2735609; US9598707; ES2644113; CA2834646; DK2735609; EP2735609; EP2735609. 
Mehrotra, S., Srivastava, V., Rahman, L. U., and Kukreja, A. K. (2015). Hairy root biotechnology-indicative timeline to understand missing links and future outlook. Protoplasma 252, 1189-1201. doi: 10.1007/s00709-015-0761-1

Michno, J. M., Wang, X., Liu, J., Curtin, S. J., Kono, T. J., and Stupar, R. M. (2015). CRISPR/Cas mutagenesis of soybean and Medicago truncatula using a new web-tool and a modified Cas9 enzyme. GM Crops Food 6, 243-252. doi: 10.1080/21645698.2015.1106063

Moghadam, A., Niazi, A., Afsharifar, A., and Taghavi, S. M. (2016). Expression of a recombinant anti-HIV and anti-tumor protein, MAP30, in Nicotiana tobacum hairy roots: A pH-stable and thermophilic antimicrobial protein. PloS One 11, e0159653. doi: 10.1371/journal.pone.0159653

Moyano, E., Jouhikainen, K., Tammela, P., Palazón, J., Cusidó, R. M., Piñol, M. T., et al. (2003). Effect of pmt gene overexpression on tropane alkaloid production in transformed root cultures of Datura metel and Hyoscyamus muticus. J. Exp. Bot. 54, 203-211. doi: 10.1093/jxb/erg014

Murthy, H. N., Lee, E. J., and Paek, K. Y. (2014). Production of secondary metabolites from cell and organ cultures: strategies and approaches for biomass improvement and metabolite accumulation. Plant Cell Tissue Organ Cult. 118, 1-16. doi: 10.1007/s11240-014-0467-7

Nürnberger, T. (1999). Signal perception in plant pathogen defense. Cell. Mol. Life Sci. 55, 167-182. doi: 10.1007/s000180050283

O'Kennedy, R., Murphy, C., and Devine, T. (2016). Technology advancements in antibody purification. Antib. Technol. J. 6, 17-32. doi: 10.2147/ANTI.S64762

Palazón, J., Cusidó, R. M., Bonfill, M., Mallol, A., Moyano, E., Morales, C., et al. (2003). Elicitation of different Panax ginseng transformed root phenotypes for an improved ginsenoside production. Plant Physiol. Biochem. 41, 1019-1025. doi: 10.1016/j.plaphy.2003.09.002

Pavlov, A., Georgiev, V., and Ilieva, M. (2005). Betalain biosynthesis by red beet (Beta vulgaris L.) hairy root culture. Process Biochem. 40, 1531-1533. doi: 10.1016/j.procbio.2004.01.001

Peebles, C. A. M., Sander, G. W., Li, M., Shanks, J. V., and San, K. Y. (2009). Five year maintenance of the inducible expression of anthranilate synthase in catharanthus roseus hairy roots. Biotechnol. Bioeng. 102, 1521-1525. doi: 10.1002/bit.22173

Perassolo, M., Cardillo, A. B., Mugas, M. L., Núñez Montoya, S. C., Giulietti, A. M., and Rodríguez Talou, J. (2017). Enhancement of anthraquinone production and release by combination of culture medium selection and methyl jasmonate elicitation in hairy root cultures of Rubia tinctorum. Ind. Crops Prod. 105, 124132. doi: 10.1016/j.indcrop.2017.05.010

Pham, N. B., Schäfer, H., and Wink, M. (2012). Production and secretion of recombinant thaumatin in tobacco hairy root cultures. Biotechnol. J. 7, 537545. doi: 10.1002/biot.201100430

Pitta-Alvarez, S. I., Spollansky, T. C., and Giulietti, A. M. (2000). The influence of different biotic and abiotic elicitors on the production and profile of tropane alkaloids in hairy root cultures of Brugmansia candida. Enzyme Microb. Technol. 26, 252-258. doi: 10.1016/S0141-0229(99)00137-4

Putalun, W., Prasarnsiwamai, P., Tanaka, H., and Shoyama, Y. (2004). Solasodine glycoside production by hairy root cultures of Physalis minima Linn. Biotechnol. Lett. 26, 545-548. doi: 10.1023/B:BILE.0000021953.50300.52

Ramakrishna, A., and Ravishankar, G. A. (2011). Influence of abiotic stress signals on secondary metabolites in plants. Plant Signal Behav. 6, 1720-1731. doi: 10.4161/psb.6.11.17613

Ritala, A., Dong, L., Imseng, N., Seppänen-Laakso, T., Vasilev, N., Van der Krol, S., et al. (2014). Evaluation of tobacco (Nicotiana tabacum L. cv. Petit Havana SR1) hairy roots for the production of geraniol, the first committed step in terpenoid indole alkaloid pathway. J. Biotechnol. 176, 20-28. doi: 10.1016/ j.jbiotec.2014.01.031

Ron, M., Kajala, K., Pauluzzi, G., Wang, D., Reynoso, M. A., Zumstein, K., et al. (2014). Hairy root transformation using Agrobacterium rhizogenes as a tool for exploring cell type-specific gene expression and function using tomato as a model. Plant Physiol. 166, 455-469. doi: 10.1104/pp.114.239392

Sevón, N., and Oksman-Caldentey, K. M. (2002). Agrobacterium rhizogenesmediated transformation: Root cultures as a source of alkaloids. Planta Med. 68, 859-868. doi: 10.1055/s-2002-34924

Sevón, N., Hiltunen, R., and Oksman-Caldentey, K.-M. (1992). Chitosan increases hyoscyamine content in hairy root cultures of Hyoscyamus muticus. Pharm. Parmacol Lett. 2, 96-99.
Sevón, N., Dräger, B., Hiltunen, R., and Oksman-Caldentey, K.-M. (1997). Characterization of transgenic plants derived from hairy roots of Hyoscyamus muticus. Plant Cell Rep. 16, 605-611. doi: 10.1007/s002990050287

Sevón, N., Hiltunen, R., and Oksman-Caldentey, K. M. (1998). Somaclonal variation in transformed roots and protoplast-derived hairy root clones of Hyoscyamus muticus. Planta Med. 64, 37-41. doi: 10.1055/s-2006-957362

Shajahan, A., Thilip, C., Faizal, K., Mehaboob, V. M., Raja, P., Aslam, A., et al. (2017). "An efficient hairy root system for withanolide production in Withania somnifera (L.) Dunal," in Production of Plant Derived Natural Compounds through Hairy Root Culture (Cham: Springer International Publishing), 133143. doi: 10.1007/978-3-319-69769-7_7

Sirikantaramas, S., and Taura, F. (2017). "Cannabinoids: biosynthesis and biotechnological applications," in Cannabis sativa L. - Botany and Biotechnology (Cham: Springer International Publishing), 183-206. doi: 10.1007/978-3-319-54564-6_8

Sivakumar, G., Yu, K. W., Hahn, E. J., and Paek, K. Y. (2005). Optimization of organic nutrients for ginseng hairy roots production in large-scale bioreactors. Curr. Sci. 89, 641-649. doi: 10.2307/24111160

Srikantan, C., and Srivastava, S. (2018). "Bioreactor design and analysis for largescale plant cell and hairy root cultivation," in Hairy Roots: An Effective Tool of Plant Biotechnology. Eds. V. Srivastava, S. Mehrotra and S. Mishra (Singapore: Springer). doi: 10.1007/978-981-13-2562-5

Srivastava, M., Sharma, S., and Misra, P. (2016). Elicitation based enhancement of secondary metabolites in Rauwolfia serpentina and Solanum khasianum hairy root cultures. Pharmacogn. Mag. 12, S315-S320. doi: 10.4103/09731296.185726

Staniszewska, I., Królicka, A., Maliński, E., Łojkowska, E., and Szafranek, J. (2003). Elicitation of secondary metabolites in in vitro cultures of Ammi majus L. Enzyme Microb. Technol. 33, 565-568. doi: 10.1016/S0141-0229(03)00180-7

Stoger, E., Fischer, R., Moloney, M., and Ma, J. K.-C. (2014). Plant molecular pharming for the treatment of chronic and infectious diseases. Annu. Rev. Plant Biol. 65, 743-768. doi: 10.1146/annurev-arplant-050213-035850

Sun, J., and Peebles, C. A. M. (2016). Engineering overexpression of ORCA3 and strictosidine glucosidase in Catharanthus roseus hairy roots increases alkaloid production. Protoplasma 253, 1255-1264. doi: 10.1007/s00709-015-0881-7

Talano, M. A., Wevar Oller, A. L., González, P. S., and Agostini, E. (2012). Hairy roots, their multiple applications and recent patents. Recent Pat. Biotechnol. 6, 115-133. doi: 10.2174/187220812801784713

Thakore, D., and Srivastava, A. K. (2017). Production of biopesticide azadirachtin using plant cell and hairy root cultures. Eng. Life Sci. 17, 997-1005. doi: 10.1002/elsc. 201700012

Thimmaraju, R., Bhagyalakshmi, N., Narayan, M. S., and Ravishankar, G. A. (2003). Kinetics of pigment release from hairy root cultures of Beta vulgaris under the influence of $\mathrm{pH}$, sonication, temperature and oxygen stress. Process Biochem. 38, 1069-1076. doi: 10.1016/S0032-9592(02)00234-0

Tisserant, L.-P., Aziz, A., Jullian, N., Jeandet, P., Clément, C., Courot, E., et al. (2016). Enhanced stilbene production and excretion in Vitis vinifera cv Pinot Noir hairy root cultures. Molecules 21 (12), 1703. doi: 10.3390/molecules21121703

Udomsuk, L., Jarukamjorn, K., Tanaka, H., and Putalun, W. (2011). Improved isoflavonoid production in Pueraria candollei hairy root cultures using elicitation. Biotechnol. Lett. 33, 369-374. doi: 10.1007/s10529-010-0417-3

Vaghari, H., Jafarizadeh-Malmiri, H., Anarjan, N., and Berenjian, A. (2017). "Hairy root culture: a biotechnological approach to produce valuable metabolites," in Agriculturally Important Microbes for Sustainable Agriculture (Singapore: Springer Singapore), 131-160. doi: 10.1007/978-98110-5589-8_7

Veremeichik, G. N., Bulgakov, V. P., Shkryl, Y. N., Silantieva, S. A., Makhazen, D. S., Tchernoded, G. K., et al. (2019). Activation of anthraquinone biosynthesis in longcultured callus culture of Rubia cordifolia transformed with the rolA plant oncogene. J. Biotechnol. 306, 38-46. doi: 10.1016/j.jbiotec.2019.09.007

Wang, J. W., and Wu, J. Y. (2013). Effective elicitors and process strategies for enhancement of secondary metabolite production in hairy root cultures. Adv. Biochem. Eng. Biotechnol. 134, 55-89. doi: 10.1007/10_2013_183

Wetterauer, B., Wildi, E., and Wink, M. (2018). "Production of the Anticancer Compound Camptothecin in Root and Hairy Root Cultures of Ophiorrhiza mungos L.," in Biotechnological Approaches for Medicinal and Aromatic Plants (Singapore: Springer Singapore), 303-341. doi: 10.1007/978-981-13-0535-1_14 
Wevar Oller, A. L., Agostini, E., Milrad, S. R., and Medina, M. I. (2009). In situ and de novo biosynthesis of vitamin $\mathrm{C}$ in wild type and transgenic tomato hairy roots: a precursor feeding study. Plant Sci. 177, 28-34. doi: 10.1016/j.plantsci.2009.03.017

Wilson, P. D. G., Hilton, M. G., Meehan, P. T. H., Waspe, C. R., and Rhodes, M. J. C. (1990). "The cultivation of transformed roots from laboratory to pilot plant," in Progress in Plant Cellular and Molecular Biology. Eds. H. J. J. Nijkamp, L. H. W. Van Der Plas and J. Van Aartrijk (Dordrecht: Springer), 700-705. doi: 10.1007/978-94-009-2103-0_105

Wongsamuth, R., and Doran, P. M. (1997). Production of monoclonal antibodies by tobacco hairy roots. Biotechnol. Bioeng. 54, 401-415. doi: 10.1002/(SICI) 1097-0290(19970605)54:5<401::AID-BIT1>3.0.CO;2-I

Woo, S. S., Song, J. S., Lee, J. Y., In, D. S., Chung, H. J., Liu, J. R., et al. (2004). Selection of high ginsenoside producing ginseng hairy root lines using targeted metabolic analysis. Phytochemistry 65, 2751-2761. doi: 10.1016/ j.phytochem.2004.08.039

Woods, R. R., Geyer, B. C., and Mor, T. S. (2008). Hairy-root organ cultures for the production of human acetylcholinesterase. BMC Biotechnol. 8, 95. doi: 10.1186/1472-6750-8-95

Xue, S.-H., Luo, X.-J., Wu, Z.-H., Zhang, H.-L., and Wang, X.-Y. (2008). Cold storage and cryopreservation of hairy root cultures of medicinal plant Eruca sativa Mill., Astragalus membranaceus and Gentiana macrophylla Pall. Plant Cell Tissue Organ Cult. 92, 251-260. doi: 10.1007/s11240-007-9329-x

Yan, Q., Hu, Z.-D., and Wu, J.-Y. (2006). Synergistic effects of biotic and abiotic elicitors on the production of tanshinones in Salvia miltiorrhiza hairy root culture. Zhongguo Zhong Yao Zu Zhi 31, 188-191.

Yang, T., Fang, L., Nopo-Olazabal, C., Condori, J., Nopo-Olazabal, L., Balmaceda, C., et al. (2015). Enhanced production of resveratrol, piceatannol, arachidin-1, and arachidin-3 in hairy root cultures of peanut co-treated with methyl jasmonate and cyclodextrin. J. Agric. Food Chem. 63, 3942-3950. doi: 10.1021/jf5050266

Zaheer, M., Reddy, V. D., and Giri, C. C. (2016). Enhanced daidzin production from jasmonic and acetyl salicylic acid elicited hairy root cultures of Psoralea corylifolia L. (Fabaceae). Nat. Prod. Res. 30, 1542-1547. doi: 10.1080/ 14786419.2015.1054823

Zhang, L., Ding, R., Chai, Y., Bonfill, M., Moyano, E., Oksman-Caldentey, K. M., et al. (2004). Engineering tropane biosynthetic pathway in Hyoscyamus niger hairy root cultures. Proc. Natl. Acad. Sci. U. S. A. 101, 6786-6791. doi: 10.1073/ pnas.0401391101

Zhou, L. G., and Wu, J. Y. (2006). Development and application of medicinal plant tissue cultures for production of drugs and herbal medicinals in China. Nat. Prod. Rep. 23, 789-810. doi: 10.1039/b610767b

Conflict of Interest: FC, CL, and MG are employed by the company Samabriva SA.

The remaining authors declare that the research was conducted in the absence of any commercial or financial relationships that could be construed as a potential conflict of interest.

Copyright (c) 2020 Gutierrez-Valdes, Häkkinen, Lemasson, Guillet, Oksman-Caldentey, Ritala and Cardon. This is an open-access article distributed under the terms of the Creative Commons Attribution License (CC BY). The use, distribution or reproduction in other forums is permitted, provided the original author(s) and the copyright owner(s) are credited and that the original publication in this journal is cited, in accordance with accepted academic practice. No use, distribution or reproduction is permitted which does not comply with these terms. 